\title{
8
}
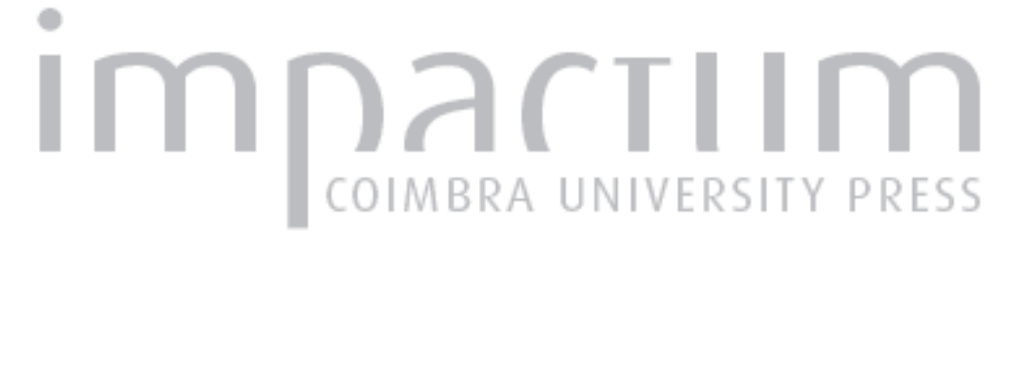

\section{Skeletal atrophy and the problem of the differential diagnosis of conditions causing paralysis}

\author{
Autor(es): $\quad$ Brothwell, Don; Browne, Sue \\ Publicado por: CIAS - Centro de Investigação em Antropologia e Saúde \\ URL \\ persistente: \\ URI:http://hdl.handle.net/10316.2/41257 \\ DOI: \\ DOI:http://dx.doi.org/10.14195/2182-7982_19_1 \\ Accessed : $\quad$ 26-Apr-2023 14:03:28
}

A navegação consulta e descarregamento dos títulos inseridos nas Bibliotecas Digitais UC Digitalis, UC Pombalina e UC Impactum, pressupõem a aceitação plena e sem reservas dos Termos e Condições de Uso destas Bibliotecas Digitais, disponíveis em https://digitalis.uc.pt/pt-pt/termos.

Conforme exposto nos referidos Termos e Condições de Uso, o descarregamento de títulos de acesso restrito requer uma licença válida de autorização devendo o utilizador aceder ao(s) documento(s) a partir de um endereço de IP da instituição detentora da supramencionada licença.

Ao utilizador é apenas permitido o descarregamento para uso pessoal, pelo que o emprego do(s) título(s) descarregado(s) para outro fim, designadamente comercial, carece de autorização do respetivo autor ou editor da obra.

Na medida em que todas as obras da UC Digitalis se encontram protegidas pelo Código do Direito de Autor e Direitos Conexos e demais legislação aplicável, toda a cópia, parcial ou total, deste documento, nos casos em que é legalmente admitida, deverá conter ou fazer-se acompanhar por este aviso.

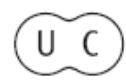


Antropologia Portuguesa

Volume $19 \cdot 2002$

Departamento de Antropologia | Universidade de Coimbra 


\title{
Skeletal atrophy and the problem of the differential diagnosis of conditions causing paralysis
}

\author{
Don Brothwell', Sue Browne \\ 'Department of Archaeology \\ University of York \\ York YO1 7EP, England \\ SSandy Corner, Ogdens North. \\ Fordingbridge, SP6 2QD, England
}

Abstract There are now quite a number of cases of skeletal atrophy, ranging from widespread to very limited extent in the body. The cases are from different populations and time periods. Usually, the pathology is considered to be the result of early trauma or a long term sequel to the poliomyelitis virus. In fact there are various alternative diagnoses to this infection, and these will be discussed in relation to some of the archaeological cases, and especially a recent find from southern England. In particular it seems important when considering such pathology to take account of all possible explanations, traumatic, infectious and genetic.

Key words Skeletons; paralysis; atrophy; polionyelitis; differential diagnosis; muscular dystrophy.

Resumo A atrofia esquehética, actualmente com vários casos descritos de diferentes populações e cronologias, pode ser limitada na sua extensão ou generalizada a todo o corpo. Geralmente, a patologia é considerada como o resultado de trauma antigo ou como sequela, a longo termo, ao vírus da poliomielite. De facto, existem vários diagnósticos alternativos para esta infecçāo que serāo discutidos em alguns casos arqueológicos e, em especial, no recentemente descoberto no Sul de Inglaterra. Em particular, parece importante ponderar todas as explicaçōes possiveis para esta patologia, como a traumática, a infecciosa e a genética.

Palavras-chave Esqueletos; paralisia; atrofia; poliomielite; diagnóstico diferencial; distrofia muscular. 


\section{Introduction}

In 1666 a man was hanged for starting a fire. He was identified by what was described as a palsied arm and leg, but we will never know what the condition really was. But we do know what he started. It was the Great Fire of London. Nearly contemporary with this event, in 1620, a medical study records the decline in health of a man of 34 years, so that by his $49^{\text {th }}$ year, he displayed atrophy of both arms and legs (McHenry, 1982). Was this a myelitis or meningitis or what?

Some centuries earlier, Bede (AD 672-735) had recorded that Abbot Benedict Biscop "after three years of creeping paralysis, was

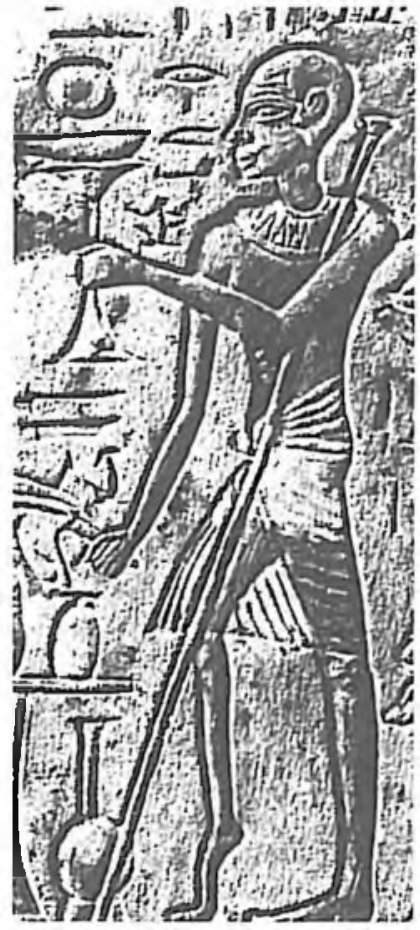

Figure 1. Possible depiction of limb atrophy in an Egyptian stele of the eighteenth dynasty. Carlsberg Glyptothek, Copenhagen. so weakened that his lower limbs were already as good as dead and only the upper part of his body... still functioned" (Gardner, 1993: 43).

In John Paul's major history of poliomyelitis, he refers to the well known and far earlier evidence of paralysis dating back to at least $1300 \mathrm{BC}$, depicting - to quote him - "a deformity so characteristic of the after effects of poliomyelitis that the diagnosis is practically assured" (Paul, 1971:12) "Here the crippled young man ... is pictured with a withered and shortened left leg, with his foot held in the typical equinus position characteristic of flaccid paralysis." In fact this has generally been the view on this Egyptian case (Figure 1) since it was first described in 1911 by Ove Hamburger, and only now does it seem to us in need of further evaluation, together with other archaeological cases.

For instance, a near contemporary of this Egyptian, but from south-east England, displays an atrophied left arm, 
which was also thought to be indicative of poliomyelitis, although Erb's paralysis was considered as an alternative (Wells, 1955).

\section{The problem of a differential diagnosis}

What we wish to do here is express our concern about the nature of diagnosis in the case of various degrees of skeletal atrophy in archaeological material. A number of cases are selected, which seem to provide a good range of pathology for debating differential diagnosis. Mechanical malfunctioning, leading to skeletal atrophy, can occur at different times in our life history, from the numerous aetiologies of the "floppy infant" syndrome to the grades of paralysis which can occur following apoplexy. Against this background of alternatives, it is surprising that poliomyelitis has been constantly preferred as a diagnosis for the various archaeological examples of skeletal atrophy.

In terms of limb involvement in poliomyelitis, only two percent of recent children display atrophy in one arm and a leg, following this disease (Levine, 1974). Usually, in fact, an arm or a leg, or both legs or both arms or both arms and legs together were involved (Table 1).

Table 1. Age and site of involvement of polio (from Levine, 1974: 112).

\begin{tabular}{|c|c|c|c|c|}
\hline \multirow[t]{2}{*}{ Body involvement } & \multicolumn{2}{|c|}{ From 0 to 5 years of age } & \multicolumn{2}{|c|}{ From 6 to 16 years of age } \\
\hline & $n$ & $\%$ & $\mathrm{n}$ & $\%$ \\
\hline One leg & 87 & 15.0 & 26 & 10.7 \\
\hline One arm & 40 & 6.9 & 23 & 9.4 \\
\hline Both legs & 125 & 21.6 & 35 & 14.3 \\
\hline Both arms & 13 & 2.2 & 9 & 3.6 \\
\hline Both arms and legs & 94 & 16.2 & 41 & 16.8 \\
\hline One arm and two legs & 34 & 5.9 & 8 & 3.3 \\
\hline Two arms and one leg & 6 & 1.1 & 2 & 0.8 \\
\hline One arm and one leg & 13 & 2.2 & 7 & 2.9 \\
\hline Diaphragm and chest & 23 & 4.0 & 13 & 5.3 \\
\hline Abdomen & 74 & 12.8 & 54 & 22.0 \\
\hline Back & 69 & 11.9 & 26 & 10.7 \\
\hline TOTAI & 578 & & 244 & \\
\hline
\end{tabular}


In Walton and Warrick's (1954) radiological study of osseous changes in myopathy (Duchenne, Erb and Landcuzy - Dejerine types, as well as dystrophia myotonica and myctonica congenita), they make the important point that disuse, whatever its aetiology, will produce the same bone changes. Age of course, especially the degree of immaturity, will also be an influence. The major difference between the progressive muscular dystrophies and poliomyelitis, is that the latter condition is likely to have a far more restricted effect on the body in general, and especially all arms and legs. The Duchenne type of muscular dystrophy is probably the most destructive skeletally, in that it progresses slowly over the childhood years, causing regularly major disuse atrophy (Emery, 2002). Few survive long into adulthood, and it is interesting to note that the potential archaeological cases all died in their late teens or early adult lives. The incidence $\left(x_{10}{ }^{-6}\right)$ appears to vary from 150 to 390 . Being a chromosome X-linked recessive, its appearance is not reliant on infection, and earlier more inbred small societies could have been ideal for its perpetuation. Compared to the mutation rate $\left(\times 10^{-6}\right)$ of 10 for achondroplasia, that for Duchenne muscular dystrophy is between 80 and 100 (Emery, 1988). Thus, of the various differential diagnostic alternatives to poliomyelitis, the Duchenne type of muscular dystrophy seems to demand our special attention and consideration. Nevertheless, we need to keep in mind other alternative diagnoses. The muscular dystrophies (Table 2) are certainly seriously neglected in archaeology, but there are further alternatives.

The major skeletal changes which can occur in cerebral palsy have similarly been ignored. It is interesting to note that today, those affected by this condition tend to live ten or twenty years more than muscular dystrophy cases (Jones, 1975). Perhaps even thyrotoxic myopathy deserves consideration (Ramsay, 1974), and here the atrophy is especially in the arms and shoulders. It is a later adult problem also. As yet there appears to be no good radiographic study of long term multiple sclerosis.

And what of the bone changes in the paralytic states produced by lathyrism, the result of eating certain leguminous plants containing a neurotoxic amino acid (Bell and Nunn, 1988). Clearly this is only the beginning of a challenging re-evaluation. 
Table 2. The largely genetically based muscular dystrophies (classification is based on Emery, 1988).

A. Chromosome X-linked

(a) Severe (Duchenne)

(b) Mild (Becker and others.)

B. Autosomal recessive

(a) Severe, resembling Duchenne

(b) Mild limb girdle (1) with facial involvement

(2) without facjal involvement

C. Autosomal dominant

(a) Facioscapulohumeral

(b) Distal

(c) Ocular

(d) Oculopharyngeal

Presumably poliomyelitis has been the favoured diagnostic condition because it has been an epidemic disease, at least in historic times, but it may be wrong to assume that it has been an important epidemic condition back into prehistory, or that it occurred regularly. With the cultivation of leguminous crops by some earlier populations, it could be argued that in some areas, paralysis from lathyrism was equally likely.

\section{Archaeological evidence for atrophy}

It is not our intention here to provide a comprehensive and exhaustive review of the ancient cases of skeletal atrophy. Rather we wish to show the variation in these cases, and consider the difficulties of differential diagnosis. The examples range from atrophy evidence in single limbs, to widespread disuse atrophy. In considering alternative diagnoses, the sex and age of the individuals were also taken into account.

Case 1. Grave 5218 in the Anglo-Saxon cemetery of Raunds in England, contained the skeleton of a young adult male. The left shoulder joint and the right knee displayed evidence of long term 
inflammatory change, as did some vertebrae (Powell, 1996). The result of damage to the growing epiphyseal areas during childhood had resulted in longitudinal retardation of the left humerus and right femur, together with associated atrophy of the related forearm and lower leg. Tuberculosis and poliomyelitis were both considered as causative agents, but childhood tubercular infection seems most likely.

Case 2. A Roman male of about 25 years was excavated at Mundford, Norfolk, and displayed multiple abnormalities (Wells, 1964). The defects included left shoulder hypoplasia with marked shortening of the left humerus and a marked atrophy of the left femur, tibia and fibula. The right side of the pelvis is larger than the left. The left tibia shaft displays an old well-healed fracture, and there appears to be a severe but healed fracture to the left distal femur. The skeleton certainly had evidence of infection, but the defects outlined could mainly have been caused by major obstetric injuries by unskilled individuals attempting delivery.

Case 3. A medieval male of between 35-50 years from Gruczno, Poland, displayed atrophic changes which were concluded to be the result of acute poliomyelitis (Kozlowski and Piontek, 2000). Only the right lower limb and pelvis was affected, as can be seen by comparing a series of skeletal dimensions for the upper and lower limb areas, and the left and right sides (Figure 2). While

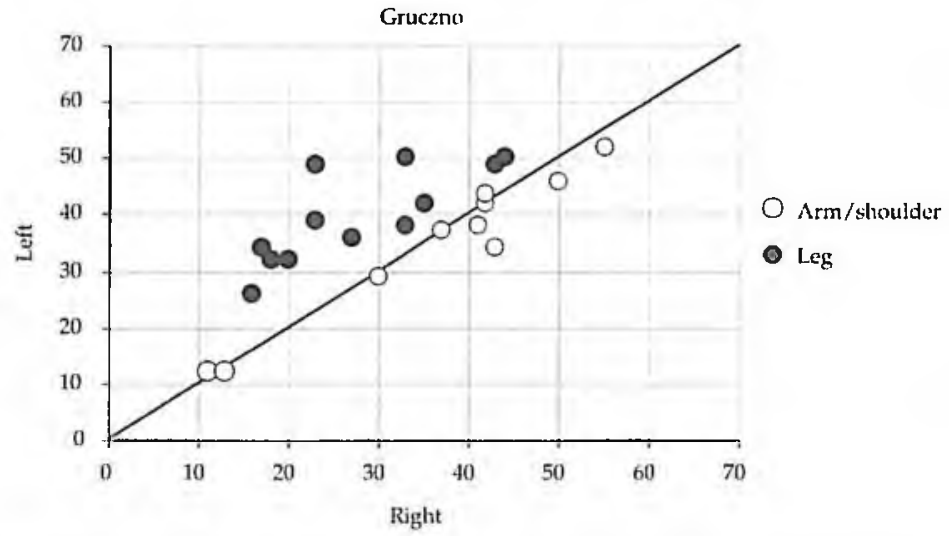

Figure 2. Comparison of the smaller bone dimensions (in mms) of the Gruczno skeleton, left and right sides. 
there is a normal degree of skeletal asymmetry in the arm and shoulder dimensions (with most measurements close to the 1.1 ratio), the leg measurements show greater differences between the two sides. Taking radiographic, metric and morphological factors into consideration, the authors concluded that acute poliomyelitis was the cause.

Case 4. In the child skeleton 2444 from the medieval Jewish cemetery (Jewbury) in York, there was clear evidence of atrophy in the left arm (Figure 3 ). The child did not survive beyond 12 years, and a diagnosis of poliomyelitis was tentatively suggested (Brothwell and Browne, 1994), although birth injury now deserves to be considered.

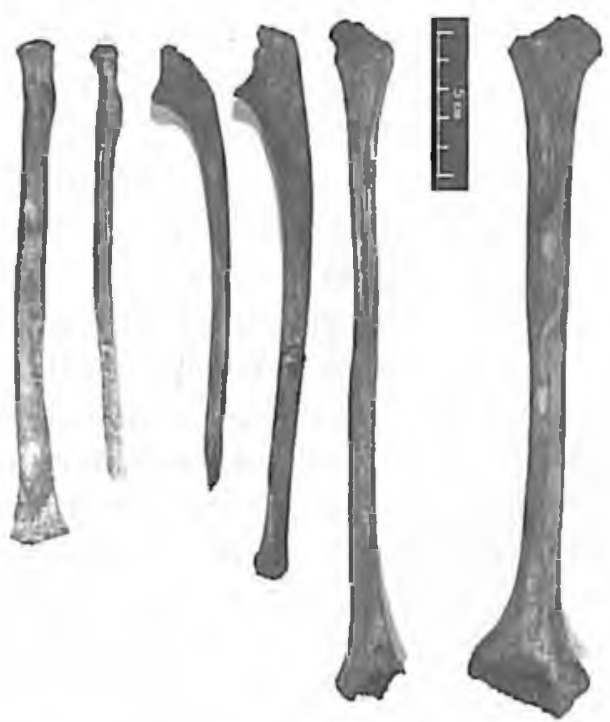

Figure 3. The long bones of the arms of burial 2444 , from medieval Jewbury, York, with clear evidence of unilateral atrophy.

Case 5. Evidence of a possible quadriplegic state is provided by an infant burial from Thailand reported by Nancy Tayles (2001). The abnormality consisted of morphological differences in the femora and an abnormal burial posture, both considered to be suggestive of cerebral palsy. 
Case 6. By far the most problematic and indeed perhaps similar cases are from the USA, Japan, the Near East and England. The first is a late prehistoric (c.1400-1500 AD) skeleton from the Juhle site in Maryland (NMNH 384120). Long bone length was normal and suggested a person of late adolescence or a young adult. In contrast to lengths, long bone widths are small and the bones look severely atrophic. The overall pathology of this skeleton initially suggested a diagnosis of osteogenesis imperfecta (Ortner, 1993), but it was acknowledged that there were no antemortem fractures, which would have been expected in such a diagnosis. So could it be muscular dystrophy?

Case 7. A similar example has been well described by Suzuki and colleagues (1984) from the Irie shell mound in Hokkaido, Japan, of the Jomon period. The individual, probably a late teenager, was relatively complete, and again all the long bones were abnormally thin and atrophied along the shafts. In the differential diagnosis, congenital, neoplastic, traumatic and infectious processes were considered, and after careful consideration of these alternatives, a diagnosis of quadriplegia caused by poliomyelitis anterior acuta (infantile spinal paralysis), was suggested. Alternatives deserve consideration.

Case 8. From Tell Abraq, in the Arabian Gulf (United Arab Emirates) a four thousand year old skeleton, with clear evidence of extensive long bone atrophy, has received preliminary description. Professor Debra Martin (2001) has very kindly provided field and laboratory data on the body, so that we could include it in this brief survey. The individual is probably female, although still a late teenager or very young adult. Dr. Martin suggests that the individual had become chronically sedentary, resulting from a neurological disease of some years duration (with some left/right side asymmetry). It can be seen from Figure 4 that differences between left and right sides, and arms compared with leg dimensions, is not as marked as in the Gruczo body. In part this is because robustness differences are not easily measurable. Poliomyelitis, multiple sclerosis or other neurological conditions were considered in a differential diagnosis. 


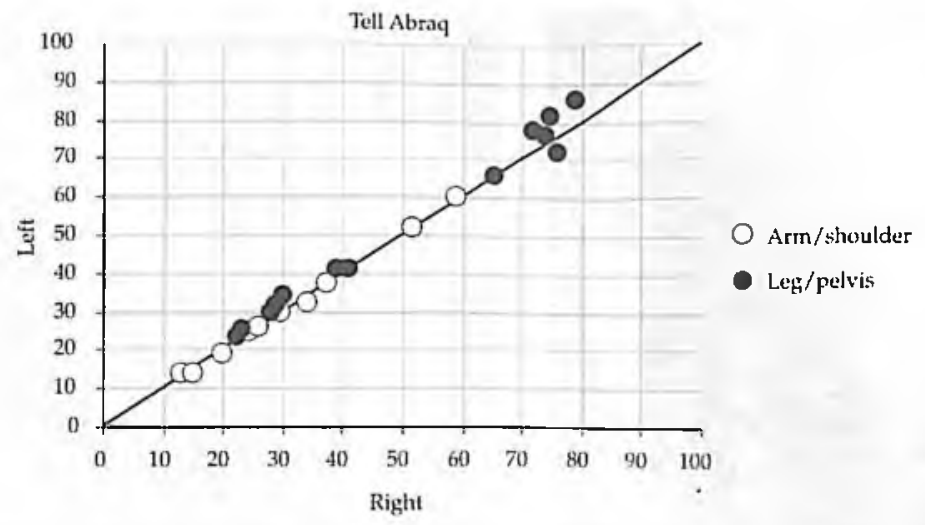

Figure 4. Comparison of the bone dimensions in the Tell Abraq skeleton (Tomb $73 / 112 b$. Burial 1), left plotted with right side.

Case 9. The final case is from Anglo-Saxon Winchester in England. The individual (SG 1109) is about fifteen or sixteen years of age, and displays long bones of normal length and articular size, but with extremely thin and atrophied shafts. For some considerable time before death, the individual could have been chair and bedridden, for it must have taken some years for the individual to have lost and remodelled the bone tissue to the extent seen in this individual. The atrophy in the long bones is clearly seen in Figure 5 . Comparison of the atrophied femur with a normal one of comparable age (Figure 6) shows clearly that shaft atrophy is considerable, but the femur head remains of normal size. This difference between shaft and articular area is also seen in the other long bones. The other

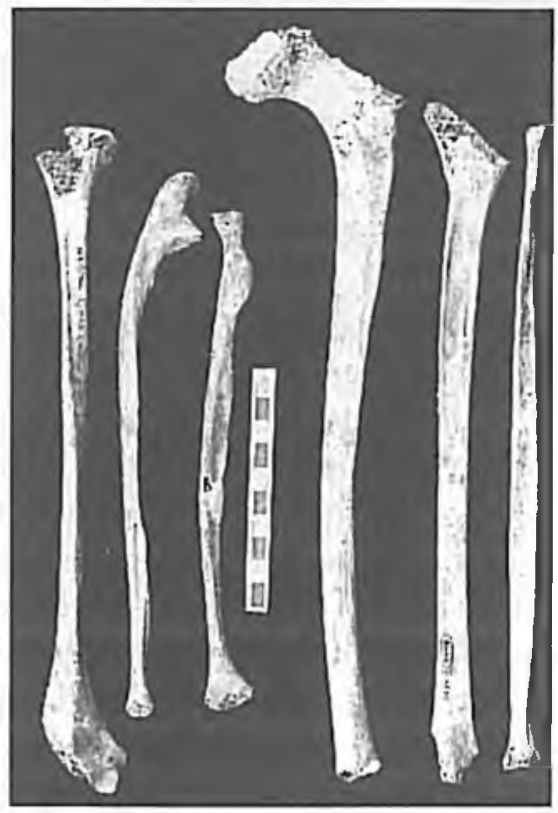

Figure 5. Severe atrophy in the skeleton SG 1109 from Saxon Winchester (courtesy, Winchester City Council). 


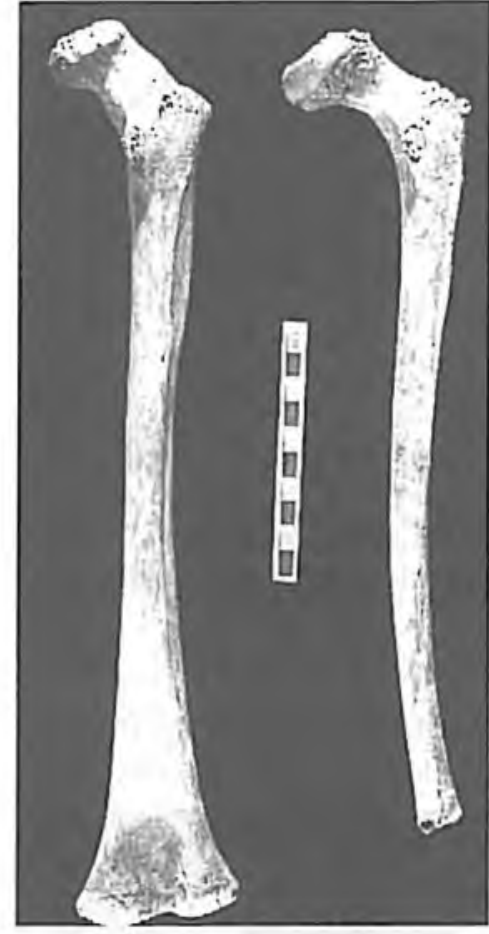

Figure 6. Comparison of a femur from SG 1109 and a normal femur (G. 1112), of a similar age.

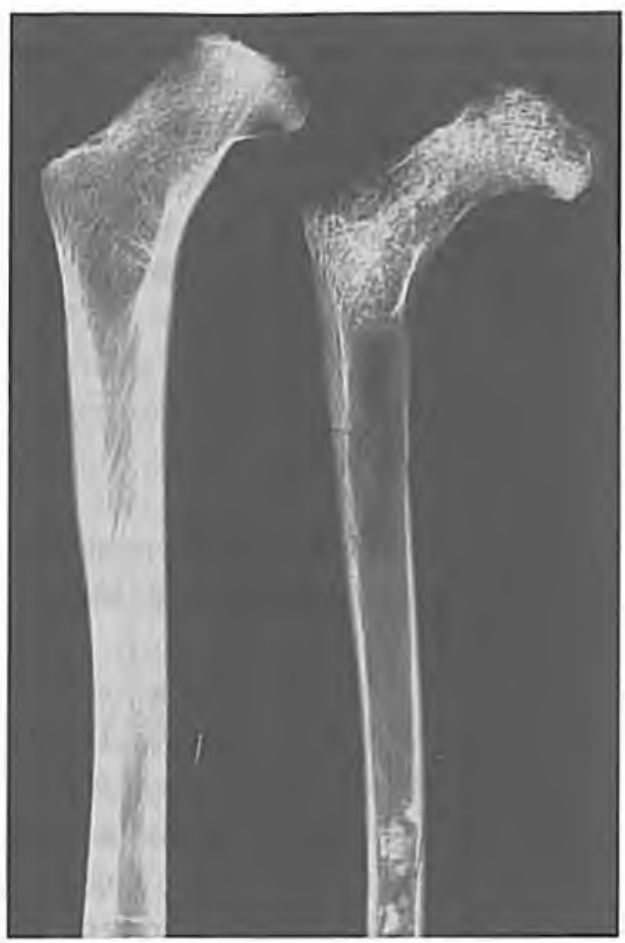

Figure 7. Radiograph of the proximal half of a femur from 5G 1109 (right) and a normal comparative femur (left).

difference, seen in X-ray (Figure 7) is in the thickness of bone cortex, which is greatly reduced in SG 1109.

The extent of the metrical reductions from normal is seen in Figure 8, where the graph of skeletal dimensions compares SG 1109 with a normal Saxon individual of the same age. Maximum lengths of the long bones are not given, and it should be noted that they appear to be normal for an individual of this age. In other words, normal longitudinal growth was achieved, but poor muscle function in both arms and legs resulted in severe long bone atrophy.

It is possible that the diagnosis of atrophy restricted to one, or perhaps two, limbs will remain a problem for some time to come unless of course associated trauma or infection may help to confirm 


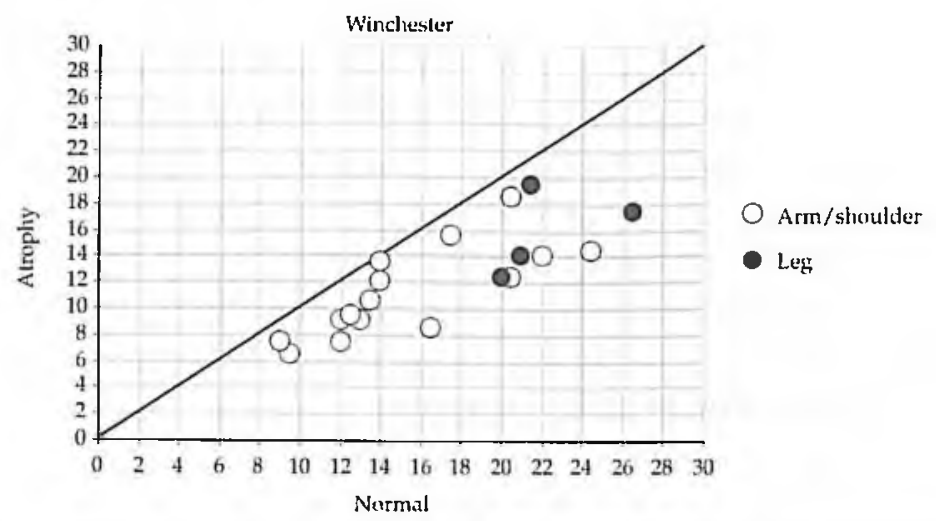

Figure 8. Comparison of the various smaller bone dimensions (in mms) of SG 1109 from Winchester, plotted against a normal skeleton of the same age.

a diagnosis. It can be argued that poliomyelitis in the past, as in recent decades is likely to leave restricted paralysis, as severe states of the disease was more likely to kill, rather than affect all limbs with severe paralysis. Cerebral palsy is very unlikely to result in symmetrical paralysis in both arms and legs, but this could occur in multiple sclerosis, although this condition is also likely to kill before widespread skeletal atrophy occurs. Lathyrism is reported to cause paralysis especially in the legs. Of special interest, therefore, are the inherited myogenic disorders, which can affect both arms and legs. In particular, the Duchenne - type of muscular dystrophy appears to cause the most extensive muscular weakness and eventual skeletal atrophy (Emery, 2002). It would thus seem reasonable to argue that the American, Japanese and English (Winchester) cases deserve reflection as possible cases of muscular dystrophy.

Sexing these skeletons, incidentally, might be far more difficult than usual, owing to the long term effects in childhood of the condition on growth.

\section{Conclusion}

Although the interpretation of the variable ancient evidence of disuse atrophy is not an easy task, there are clearly some 
guidelines to follow. Associated pathology, or the limited nature of the atrophy may suggest, for instance, trauma or tubercular paraplegia. The diagnosis of poliomyelitis is perhaps most likely if single or paired limbs display severe atrophy - but without any associated infectious or arthritic joint involvement. Far more extensive atrophy involving all limbs, would surely argue for the possibility of a Duchenne type muscular dystrophy. Having said that, more research is clearly needed on diseases which can produce wasting and skeletal atrophy.

\section{Acknowledgments}

We are most grateful to Kenneth Qualmann, Head of Museums Service, Winchester City Council, for providing the opportunity to study the Winchester case (SG 1109). Also our thanks go to Professor Debra Martin of Hampshire College, Massachusetts, for providing details of the Tell Abraq case.

\section{Bibliography}

Bell, E.; Nunn, P. 1988. Neurological diseases in man - are plants to blame? Biologist, 35: $39-42$.

Brothwell, D.; Browne, S. 1994. Pathology. In: Lilley, J.; Stroud, G.; Brothwell, D.; Williamson, M. (eds.). The Jezvish Burinl Ground at Jewbury. The Archneology of York. York, Council for British Archaeology, 12(3): 291-578.

Emery, A. E. 1988. Duchenne Muscular Dystrophy. Oxford, Oxford University Press.

Emery, A. E. 2002. The muscular dystrophies. The Lnncet, 359(9307): 687695.

Gardner, R. 1993. Medicine in Anglo-Saxon Northumbria. In: GardnerMedwin, D., Hargreaves, A.; Lazenby, E. (eds.). Medicine in Northumbria. Newcastle, Pybus: 40-57.

Hamburger, O. 1911. Un cas de paralysie infantile dans l'antiquité. Bulletin de In Société Française d' Histoire de la Mëdecine, 11: 407-412. 
Jones, M, H. 1975. Differential diagnosis and natural history of the cerebral palsied child. In: Samilson, R. (ed.). Orthopaedic Aspects of Cerebral Palsy. London, Heinemann, Spastics International Medical Publications: 5-25.

Kozlowski, T.; Piontek, J. 2000. A case of atrophy of bones of the right lower limb of a skeleton from a medieval $\left(12^{\text {th }}-14^{\text {th }}\right.$ centuries $)$ burial ground in Gruczno, Poland. Joumal of Paleopatiology, 12: 5-16.

Levine, D. B. 1974. Poliomyelitis. In: Hardy, J. H. (ed.). Spinnl Deformity in Neurological and Muscular Disorders. Saint Louis, Mosby: 111-139.

Martin, D. L. 2001. Personal communication on Tell Abraq skeleton.

McHenry, L. C. 1982. Neurology and art. In: Rose, F.; Bynum, W. (eds.). Historical Aspects of the Neuroscicnces. New York, Raven Press: 481-519.

Ortner, D. J. 1993. Bone growth and paleopathology. In: Hall, B. K. (ed.). Bonc Growth. London, CRC Press. Vol 7: Bone Growth: 159-178.

Paul, J. R. 1971. A History of Poliomyelitis. New Haven, Yale University Press.

Powell, F. 1996. The human remains. In: Boddington, A. Rnunds Fumells: The Anglo-Saxon Church and Churchyard. London, English Heritage: 113-124.

Ramsay, I. 1974. Thyroid Disense and Muscle Dysfunction. London, Heinemann.

Suzuki, T.; Mineyama, I.; Mitsuhaksi, K. 1984. Paleopathological study on an adult skeleton of Jomon period from Irie shell mound, Hokkaido. Journal of the Anthropological Society of Nippon, 92: 87-104.

Tayles, N. 2001. Is this a case of cerebral palsy? Paleopathology Nezusletter, 114: 9-10.

Walton, J.; Warrick, C. 1954. Osseous changes in myopathy. British Joumal of Radiology, 27: 1-15.

Wells, C. 1955. Early Bronze Age burials at Barton Bendish, Norfolk: the human skeletal remains. Norfolk Archaeology, 31(2): 225-228.

Wells, C. 1964. An early case of birth injury: multiple abnormalities in a Romano-British skeleton. Developmental Medicine and Child Neurology, 6: $397-402$. 